\title{
'All the King's Horses and All the King's Men couldn't put Humpty-Dumpty Together Again'
}

\section{Piotr Dutkiewicz and Gavin Williams}

\section{Crises of State Policy}

In most African countries today, there are evident crises of state policy. These are now of some years standing and they extend to numerous aspects of the social, cultural, political and economic lives of the people of the different countries.

Their most obvious manifestations are:

1. large foreign debts (to private and to public international banks);

2. more critically, Africa's high level of dependence on imports to maintain local production as well as to meet consumption needs directly;

3. Africa's declining capacity to produce commodities for export and to maintain world market shares of exports, combined with poor prices and poor prospects for their products; and

4. poor integration of different sectors of the economy and particularly public investments, so that money spent does not expand production of goods to meet people's needs

There is no one common crisis across Africa. Contrary to World Bank regional diagnoses or media representations of distress and starvation in "Africa", the major problems in Mali are not the same as those in Nigeria; those of Ethiopia are not the same as those in Tanzania.

If there is one thing which the independent countries of Africa do share it is, firstly, the centrality of state activity in attempting to direct and manage their diverse problems. Secondly, it lies in the widespread failure of state policies to implement their intended objectives, let alone to solve the problems faced by the people of the countries concerned.

\footnotetext{
This paper was discussed at a conference at the Institute of Development Studies and we are grateful for their comments to partcipants, especially Yusuf Bangura. Björn Beckman. Teddy Brett. Hugh Roberts. Gordon White and Ann Whitehead, as well as to Bill Freund. and wish to thank the British Council for making it possible for Piotr Dutkiewicz to attend the IDS conference. The paper both borrows from and responds to arguments by and discussions with colleagues in different countries, notably Tajudeen Abdulraheem, Robert Bates, Sara Berry. Henry Bernstein. Manfred Bienefeld. Tom Callaghy. Naomi Chazan. Fred Cooper, Phillip Corrigan. Tom Forrest, Judith Heyer, Rauf Mustapha. 'Bayo Olukoshi, Segun Osoba. Shehu Othman. Richard Palmer-Jones, Pepe Roberts. Igor Sledzevsk t. Ewa Szulc. Terisa Turner, Mike Watts and Dan Zelikow. Our greatest debt is to Bob Shenton.
}

The primary contradictions in contemporary Africa arise from the complex of ways in which surplus value is appropriated from producers by the ruling classes and their foreign and local associates. The central and direct involvement of the state in the process of surplus appropriation leads to continuing expansion of the scope of state activity. However, this leads to the 'diminishing reproduction' [Dutkiewicz and Shenton 1986] of the social resources on which the state depends for its own reproduction, and of its capacity to appropriate those resources and direct them to its own purposes. In turn this generates a series of further contradictions, among state institutions, among different groups and classes, and between the centre and localities as each pursues its ends to the detriment of one another. Cooperation is fragile and temporary; antagonism and exclusion are the dominant motifs of such a system.

\section{The Intractability of Reforms}

Formulae abound for dealing with complex problems by addressing one element. without attending to their wider and historically structured context. Thus governments are told to "get prices right', as if they had instruments to divine and diagnose correct prices, or to "return to the market' as if "it already existed as a neutral and impersonal mechanism for allocating resources. They are advised to solve problems of food production by diffusing technological innovations among receptive 'progressive' farmers without respect for the experience. practical knowledge and scepticism of peasant producers. Problems of public sector management are to be solved by invoking "Management By Objectives' and 'Performance and Programme Budgeting and their acronymic progeny. To deal with several problems at once, development projects are relabelled 'Integrated Development Projects'. To eliminate corruption and inculcate socially responsible behaviour, campaigns may be initiated to make 'War on Alcoholism' or to conduct a 'War Against Indiscipline'.

States, and their official and academic spokesmen, elaborate such formulae as symbols for the real and complex issues which they cannot grasp. Chasing symbols becomes the self-perpetuating task of bureaucracies. When we fail to solve the problems of the present, we are tempted to try to return to the past. 
Such a past can only exist as a symbol for the ills of the present. We cannot always solve present problems by reversing past errors since this will neither restore the previous situation nor create the conditions for overcoming problems.

The International Monetary Fund and the World Bank are now sponsoring programmes of 'structural adjustment' as a condition of sustaining the access of client governments to international credits, public and private. They recognise that reforms need to be comprehensive if they are to be successful. They typically press governments to reduce spending, especially on public services, and to cut the real wages of workers, to raise interest rates and to lower the exchange rates of their currencies, to free trade, internal and external, from government controls and to allow prices to be set in line with the costs of services and the supply and demand of commodities. These are not so much a way of making governments pay off their debts as of negotiating the terms on which they do not pay them.

The results have often proved disappointing. In the process of formulating and implementing policies, some recommended measures are dropped in the face of opposition from varied interests and resistance from workers; others are only partly carried out. The pattern consists of rising costs of living, shortages of essential imports, declining living standards for most people, falling values of national currencies and rising foreign debts.

These problems do not affect all African countries equally - though none are exempt from all of them. What we outline in this paper is not a generalised description of contemporary Africa but an ideal-type, in Max Weber's sense ]1970:90], an analytical construct which identifies and accentuates, from a one-sided viewpoint, aspects of the concrete phenomena which are more or less present and occasionally absent in the different African countries. We analyse the dynamics which such phenomena generate and which undermine attempts to deal with their consequences. We seek to explain why the problems faced in many African countries appear to be so intractable and why attempts to bring about reforms 'from above' so often prove unsuccessful.

\section{The Colonial State}

The construction of capitalist, just as much as of socialist economies, required the prior formation of the modern state. In Africa, the colonial form of the modern state expanded the scope for commodity production and the activities of capitalist enterprises, both foreign and indigenous.

From the outset, colonial states in Africa acted to establish the administrative, legal, fiscal and financial conditions for capitalist firms to operate. They paid for the building of the railways and, selectively, of a road network. They responded variously to the economic requirements of certain clients, recruiting labour and regulating its movement to meet the needs of mining companies, plantations and settler farms. In economies such as Nigeria, Ghana or Uganda the capacity of peasant smallholders to expand production of export crops and the interests of colonial firms trading in these crops encouraged colonial policies designed to favour peasant producers over plantations or settlers. The colonial administration intervened little in the production and distribution of crops. Colonial firms consolidated their oligopolistic control over commodity imports and exports to the exclusion of African traders.

Between the two world wars, African producers of crops for export and local markets suffered from precipitous falls in prices in 1921, 1929, 1931, 1934-35 and 1937. After 1921, prices never returned to their pre-war levels and in the 1930s were generally below half the levels reached in 1927-28. Increased dependence on cash income to pay for socially necessary consumption and taxation, and a lack of alternative sources of income, meant that commodity exports continued to expand during this period. For foreign trading companies the 1930 s saw a succession of speculative booms, followed by collapsing prices and crises of profitability in export markets. They blamed their problems on 'middlemen', formed cartels ('pools') and invoked the support of the state to try and pass the costs of the crisis on to African producers of export crops and consumers of imported goods.

For the colonial state, the 1930 s was therefore a period of falling revenues from imports and exports (and sustained levels of direct taxation) and one of political unrest as well as of economic instability. The state was called in to intervene directly in regulating crop marketing and forming cooperatives, and state officials increasingly lost confidence in leaving economic activities to markets and acquired a belief in the virtues of state regulation and direction of economic activity. The colonial state came to see itself as responsible for promoting 'colonial development and welfare', and the imperial government passed successive acts declaring these objectives.

The lack of financial and administrative resources limited the scope for state economic intervention in the 1930s. The requirements of the Second World War and the demands of post-war reconstruction of the metropolitan economy provided both the need and the opportunity for the state to extend its responsibility for regulating, managing and undertaking economic activities. The post-war period saw a coming together of etatiste theories, specific measures of state intervention and a more general extension of state regulation of critical aspects of the economy. Herein lies the origin of the contemporary "developmental state'. 


\section{The 'Developmental State'}

The colonial state first took control of exports and imports during the war. They were organised into state monopolies and as state-regulated private obligopolies. State monopolies and regulation were continued after the war to manage colonial resources to meet the needs of the reconstruction of the metropolitan economies.

The state controlled access to critical and expanding sources of funds and of economic advantages. It appropriated resources from export producers through its control of prices and taxes making them available for redistribution. The state allocated contracts and licences to buy and sell specific commodities.

During the 1950 s export prices improved for most primary commodities. They paid for increased employment, wages, education, investments in transport and imports. Import and exchange controls were relaxed or abandoned. However there was no revival of the pre-war economic structure. State management and regulation of marketing, expanded levels of state expenditure and a commitment to state promotion of development were enduring legacies of war-time and post-war changes.

Political power was transferred to politicians who succeeded in articulating the demands of different classes and social groups in the alternating languages of nationalist ideology and of ethnic solidarities. New ethnic as well as national identities came to be defined around the administrative and electoral structures set up by the colonial state. Control of political and administrative office became in turn the means for creating constituencies of state beneficiaries and clients.

Administrative and political decisions tended to become more centralised, moving upwards from local level 'Native Authorities' to regional and central government. Central and regional governments used their powers to determine the finances and policies of, and tenure of office in, subordinate local authorities which became clients of the central government.

Through its capacity to allocate material resources and economic opportunities to its beneficiaries, the state is able to shape the class structure of society and the allocation of class positions within it. Share power offered African politicians and businessmen a means of displacing foreigners from their domination of foreign and, in some cases local, trade. By regulating access of foreigners to African markets they were able to negotiate a more lucrative partnership with foreign firms on whom they continue to depend for credit, supplies, management and technical services.

The elaboration of state controls, increasing dependence on state decisions and the concentration of lucrative opportunities in state hands leads to a centralising of decisions within the state itself in the hands of a 'political class' of politicians, civil and military officials, and their close associates. The central state itself comes to determine the outcome of regional and local conflicts and thus, as it appropriates more decisions to itself, to become the focus of political competition and conflict. Unable, therefore, to arbitrate among competing claims, the state produces factional conflicts within its own bureaucracy and among groups in society at large.

Lacking the means to meet public expectations and to legitimise its authority throughout the whole society, the political class seeks to legitimate its authority by offers to different client groups, defined in regional and ethnic, and also in institutional, terms to protect their interests and to prevent others from excluding them from access to resources. This generates an atmosphere of factionalism and tribalism. Unable to translate their policies into practice, the state, and the political class, resort to corruption, extortion and protectionism to pursue their objectives. State authority depends more and more exclusively on control of the means of coercion, but the coercive capacity of the state may become privatised

Political instability encourages the political class to take what they can while the going is good and, if they take thought for the morrow, to invest it abroad. Fear of the consequences of exclusion from state office leads the factions which make up the political class to take advantage of all legitimate and illegitimate means at their disposal to pursue and to keep power.

\section{The Expansion of the 'Developmental State'}

The state became the main inst rument of international and domestic capital for the pursuit of private and public goals. It came to define and determine who would be able to make which decisions, of administrative, political and economic significance. Political and administrative positions became the most fruitful means of securing economic resources and controlling economic opportunities.

The claim of the state to define public goals and the legitimate means for pursuing private goals is formally recognised in the notion of 'national sovereignty'. The expansion of state economic management is justified by the notion of 'national development'. Each new problem tends to call forth new state initiatives and institutions for dealing with them. Consequently, periods of crisis tend to produce an effusion of bureaucratic agencies.

The state and its beneficiaries seek to extend their reach into society and expand the arenas of social and economic activity within their sphere of decisionmaking. The power arising from the capacity to allocate resources depends on the exclusion of alternative courses of access. Consequently, politicians and administrators are inclined to organise the 
provision of services and the exchange of commodities along monopolistic lines. The tendencies to political oligarchy complement the tendencies to economic obligopoly and each reinforce one another.

The increase in the scope of the state's activities is matched by an expansion of the claims made upon it by a variety of clients. The range of activities undertaken by the state soon exceeds both the administrative resources available to it, and its capacity to raise revenues to pay for them. Foreign personnel ('experts') can be imported, very expensively, to meet some of the 'manpower' deficiencies. Foreign aid pays for the expansion of the developmental state'.

State development policies tend to try to reproduce the industrial revolution, usually in its nineteenth century forms. 'Import-substituting industrialisation' substitutes one form of imports for another, and intensifies import dependence by making local production depend on the supply of imported goods and materials. The foreign exchange costs require increased exports of primary products. Production of consumer goods (beer, cigarettes, textiles) is followed by investment in basic producer industries (such as iron and steel, and petrochemicals) and technologically advanced industries (such as cars, tractors and trucks). Value added locally tends to be smaller (obscured by high levels of protection) and import dependence and state funding greater than with initial industries. The development of these industries exaggerated the lack of integration among economic sectors.

Rural development projects extend the state's reach into the countryside. They seek to direct farmers' production in accordance with the priorities of state policies and the current fashions in international agencies. They substitute technical and managerial solutions for changes in the conditions under which farmers adopt particular methods of production and respond to economic opportunities. They commonly feature the expensive distribution of imported technologies inappropriate to local economic and ecological conditions and ignore the practical knowledge of farmers themselves.

African countries inherited export marketing monopolies, which could easily be used to impose high taxes on export producers and to avoid raising direct taxes from employees or farmers and, often, any taxes at all from traders and businessmen. State dependence on taxing exports and imports to meet current revenue needs makes it difficult to reduce taxes when prices fall. The result is falling prices for export crops, while state expenditure increases other economic opportunities, particularly in urban areas. Not surprisingly, the volume, price and world market shares of export crops of several African countries have fallen - though others, such as the Ivory Coast, with more considered price policies, have benefited from expanding their own production and selling their neighbours' products.

State marketing monopolies, and regulations, create private and often localised oligopolies under state patronage. Some African states have sought to monopolise the marketing of local, and imported, food and of basic consumer items. The aim may be to reduce the cost of living, particularly for urban consumers. Price controls may be imposed on basic commodities. The results of these measures are to pass the costs of state marketing and private black markets on to consumers and producers. They discourage production for official markets, create scarcities and encourage speculative hoarding.

\section{The Crises of the 'Developmental State'}

The 'developmental state' generates a revenue crisis and a foreign exchange crisis. The fiscal crisis of the 'developmental state' extends to scarcities of imported and locally-produced goods, to the poor provision and even breakdown of essential services, such as water, power or transport. Health and education services decline and public sanitation deteriorates.

States may print money to cover their internal commitments. This produces an increase in claims for scarce, especially imported, goods and thus monetary inflation and a fall in the effective exchange value of the local currency. The combination of expenditure commitments, industrialisation strategies and agricultural policies left most African states unable to respond flexibly to the dramatic changes in the international economic environment since 1970. The most obvious way of filling the foreign exchange gap is to attract foreign investments, foreign aid and foreign loans. However, both aid and investments tend to encourage import dependence and rarely generate the export earnings needed to repay their foreign exchange costs.

Mineral exporters (such as Zaire, Zambia and later Nigeria) were briefly able to take advantage of rising prices of their exports to raise loans from foreign banks, but not to sustain the costs of interest and repayments when export prices fell, import costs rose and interest rates increased. The poorest countries continued to rely on aid transfers, without avoiding rising debts. Most African countries have delayed payments of commercial debts, thus raising the costs of imports. Today, some African countries are effectively bankrupt and become the international equivalent of the long-term 'structurally unemployed' in industrial capitalist countries.

The shortage of resources, the inflation of demands, especially for imported goods, and the fall in the effective exchange rates of the currencies leads states to adopt policy instruments intended to manage the allocation of scarce resources by direct controls. 
Unable to reduce the foreign-exchange costs of imported goods and foreign debts, states attempt to lower these costs in local currencies by maintaining the official exchange rate of their currencies and monopolising their exchange into convertible currencies. Concomitant restrictions are placed on the import of goods. State officials thereby acquire control of the right to acquire foreign exchange and imported commodities at prices far below those available to others. In effect, they distribute licences to print money. These measures do nothing to increase the country's import capacity. Rather the reverse is the case. Foreigners avoid any direct investment in the economy. They prefer to sell services or to realise profits by raising the import costs of commodities.

Productive activities are constrained by the unavailability of imported (or even locally-produced) parts, tools and materials. Access to them depends on becoming clients of state officials, or their patrons. Businessmen become importers, and realise higher returns from importing goods than from organising their production. State officials, in their turn, become businessmen, privatising state resources to their own profit.

Prices of exports, expressed in local currencies, are reduced relative to prices in convertible currencies. Producers are penalised from producing for export through official channels. They are encouraged to sell goods across borders to countries with stronger currencies and to use the proceeds to import commodities. Controls constrain the growth of the market for local products, increase the risks, costs and profitability of cross-border trade, and penalise interAfrican, relative to intercontinental, trade. Africans as well as foreigners with access to foreign exchange have every incentive to export money and to hold it abroad.

Bribery and corruption become the normal form of official transactions, at all levels of the state apparatus, and a necessity for engaging in private economic activity. People come to involve themselves exclusively with producing for their own needs and those of their immediate families. Concern for public matters gives way to the pressing need to solve private problems. Faced with falling incomes and scarcities of goods, public employees often devote their time, attention and whatever public resources they can use to private economic activities and to extorting payments from the public. The outcome of the process of expanded etatisation is a complex of crises involving not only economic and political institutions, but the culture of the society itself.

The involution of the authority of the state and its agencies over society encourages an appeal to symbolic means to realise social goals. Shortages of goods are blamed on 'middlemen' or better, 'middlewomen'. 'Aliens' or minorities become scape- goats for both the economic problems and the moral ills of society.

\section{The Contradictions of Reform from Above}

The expanded scope of state activity and regulation has the consequence of reducing the state's capacity to manage and control. Only through a contraction of its sphere of activities could the state regain some of its ability to direct changes in accordance with its own policies.

Partial reforms tend to be ineffective in the absence of comprehensive changes in the social, political and economic environment. For example, the abolition of state export monopolies may offer private traders a means of acquiring and transferring foreign exchange abroad, in a situation where local currencies are unconvertible and overvalued. Improved prices for export crops may not stimulate increased official sales unless adequate transport is available and payment is made promptly in a currency in which desired goods can readily be purchased. Currency devaluation will not eliminate black markets and may not stabilise the effective exchange rate if the import of highly desired items is controlled or if access to foreign exchange is limited to a closed circle of banks and the priority clients. Given an unequal distribution of income and the means of acquiring it, free importation may provide more quickly for the consumption patterns of the rich than for obtaining the means to expand local production or to meet the demands of poor producers.

The question is not whether the crises of the political economy will produce a fall in imports and a decline in living standards, but how this will take place and how the costs of austerity will be distributed. Since they can do little to change the conditions under which they operate, individuals and groups will try to solve the problems created for them by state policies by seeking to manipulate state decisions to favour themselves at somebody else's expense or even initiating new instruments of state action to meet their particular needs. State power provides access to marketable resources, and money can buy state favour; consequently the rich and powerful are better placed than anyone else to protect their position from the consequences of any form of austerity programme.

Lacking an effective capacity to direct economic and social changes, state officials are especially loth to sacrifice such controls as they have. Economic and political reforms designed to relax state control and central management tend to be qualified by measures designed to limit any untoward decisions by economic agents or local officials. In a situation of increasing scarcity the private interests of the political class can only be secured by maintaining those levers which the state can provide for appropriating public funds.

Sustained appropriation from declining resources 
creates a political economy in which profits and power depend on people's ability to find and to create opportunities to command scarce resources, and thus to perpetuate scarcities rather than to find ways of ending them.

The instability of the political class to deal with the problems of their society may lead to a consolidation of oligarchic rule and a stagnation of political life. At the opposite extreme, they may produce an escalation of military and civil violence. Those who make up the political class may adapt the system to deal with the problems generated by its own contradictions. Successive adaptations produce a cycle of renewal, reform and repression.

Public frustration arises with the inefficiency of the management of the economy. Public discontent may be manifest in various ways. Strikes, often with 'economic' origins and demands, may provide a focus for wider, political grievances. Local resistance may challenge central authority - and expose the governments' dependence on military repression. Military interventions may capitalise on public anger and generate expectations of better times. So may a return from military to elected government. New political leaders may carry out exemplary punishment of previous wrongdoers. They may offer positions of political influence to radical intellectuals and labour or popular leaders. People are promised an end to corruption and exhorted to work hard, behave honestly and soberly and support the new political order.

The new rulers use the instruments provided by the system to deal with some of its most glaring inadequacies. Changes are limited by the resources, political as well as economic, available to them. Such adaptations through crises are generally too long delayed, inadequate to the new situation, yet costly to most people, and are liable to add new problems and new institutions to compound the difficulties they inherited.

\section{The Need for Democracy}

If Africa's problems are unlikely to be resolved by reforms from above, what are the prospects that they might be cured by changes initiated from below? A further, and rather different article would be required to explore this question adequately. Here we can offer only brief reflections.

During and since the colonial period, oppressed classes and groups have demonstrated their capacities to resist particular forms of exploitation and repression. They gave support to movements for national independence. In several countries they have sustained costly and bitter wars of liberation. In others they have contributed to bringing about radical changes in who controls state power. They benefited from the dismantling of the structures of racial exclusion and in many countries workers increased their incomes and farmers gained access to land and to markets in the periods just before and just after independence. Oppressed groups and classes will find ways of evading the controls which the state seeks to extend over their economic, political and social activities and will even find means of turning some state activities to their own advantage.

However, even under socialist governments, they have rarely benefited for long from the structure of controls and regulation erected by the state. The advantages which the independent states of Africa could provide have generally been appropriated disproportionately by the rich and powerful; the costs have usually fallen most heavily on workers and peasants. Both "socialist' and 'capitalist' governments may be counted among those who have seriously mismanaged their national economies. The 'developmental states', in both their socialist and capitalist versions, have too often done little of what they could and should do, and too much of what they cannot or should not do, and much of that badly.

The poor may look to, or hope for, a new leader who will rule in their interests. However, a series of vanguards, of nationalist politicians, military officers and revolutionary leaders, have failed to use state power to meet the needs of the majority of the people. The task for socialists is not to seek a short cut to power through a military or civilian coup d'etat. The priority is to develop democratic trade unions, farmers organisations and political parties, accountable to their members and vigorous in advancing their interests and to fight for the establishment and defence of democratic political institutions. People can best protect their interests, define their goals and learn to govern themselves through participation in democratic politics.

\section{References}

Dutkiewicz, Piotr and Robert Shenton, 1986. 'Crisis in Africa: "Etatization" and the Logic of Diminished Reproduction', Review of Afican Political Economy 37, pp 108-15

Weber, Max, 1970, "Objectivity" in Social Science and Social Policy' (1904) in The Merhodology of the Social Sciences (tr. and ed. E. Shils and H. Finch), Free Press, New York 